\title{
PENGARUH MODEL PEMBELAJARAN BERBASIS MASALAH (PROBLEM BASED LEARNING) DENGAN TIPE GROUP INVESTIGATION (GI) TERHADAP HASIL BELAJAR SISWA
}

\author{
Lara Pebriana $^{1}$, Sukib Sukib ${ }^{2}$, Eka Junaidi ${ }^{2}$ \\ ${ }^{1}$ Mahasiswa Prodi Pendidikan Kimia FKIP Universitas Mataram, Indonesia ${ }^{2}$ Dosen Prodi \\ Pendidikan Kimia FKIP Universitas Mataram, Indonesia *Korespondensi, telp/fax: 081916887657, \\ email: larapebriana07@gmail.com
}

\begin{abstract}
Abstrak
Penelitian ini bertujuan untuk mengetahui pengaruh model pembelajaran berbasis masalah (Problem Based Learning) dengan tipe Group Investigation (GI) terhadap hasil belajar materi pokok larutan elektrolit dan nonelektrolit pada siswa kelas X MIA SMAN 1 Labuapi Lombok Barat. Jenis penelitian ini merupakan quasy eksperimen dalam bentuk nonequivalent control group design post-test only. Populasi dalam penelitian ini meliputi siswa kelas X MIA SMAN 1 Labuapi. Metode yang digunakan untuk pengambilan sampel yaitu dengan metode purposive sampling. Sampel pada penelitian ini yaitu kelas X MIA 2 sebagai kelas eksperimen dan kelas X MIA 1 sebagai kelas kontrol. Pada kelas eksperimen diberi perlakuan dengan menggunakan model pembelajaran berbasis masalah (Problem Based Learning) dengan tipe Group Investigation (GI) sedangkan pada kelas kontrol diberi perlakuan dengan menggunakan model pembelajaran (Problem Based Learning). Uji hipotesis pada penelitian ini menggunakan uji-t. Hasil uji statistik uji-t thitung pada taraf signifikan 5\% menunjukkan $\mathrm{t}_{\text {hitung }}(0,542)<\mathrm{t}_{\text {tabel }}(2,021)$ yang berarti $\mathrm{H}_{\mathrm{o}}$ diterima dan $\mathrm{H}_{\mathrm{a}}$ ditolak. Berdasarkan hasil tersebut maka dapat disimpulkan bahwa tidak terdapat pengaruh yang lebih baik dari penerapan model pembelajaran berbasis masalah (Problem Based Learning) dengan tipe Group Investigation (GI) terhadap hasil belajar materi pokok larutan elektrolit dan nonelektrolit pada siswa kelas X MIA SMAN 1 Labuapi Lombok Barat.
\end{abstract}

Kata kunci: model pembelajaran berbasis masalah, dan Group Investigation (GI) dan materi larutan elektrolit dan nonelektrolit.

\section{THE EFFECT OF PROBLEM BASED LEARNING USING GROUP INVESTIGATION (GI) TYPE TOWARD STUDENT LEARNING OUTCOMES}

\begin{abstract}
This study aims to determine the effect of Problem Based Learning using Group Investigation (GI) type toward learning outcomes of main subject of electrolyte and nonelectrolytes solution of MIA X CLASS SMAN 1 Labuapi West Lombok. The type of research is a quasy experiment in the form of nonequivalent control group design post-test only. The population in this study includes students of $X$ MIA class SMAN 1 Labuapi. The method used for sampling is purposive sampling method. The sample in this study is X MIA 2 class as an experimental classw and X MIA 1 class as control class. In the experimental class were treated by using Problem Based Learning with Group Investigation (GI) type while in the control class is treated by using the learning model (Problem Based Learning ). Hypothesis test in this research using t-test. The result of $t$-test statistic test $t_{\text {count }}$ at $5 \%$ significant level shows $(0,542) t_{\text {count }}<(2,021) t_{\text {table }}$ which means $H_{o}$ accepted and $H_{a}$ rejected. Based on these results it can be concluded that there is no a better influence from the application of the Problem Based Learning using Group Investigation (GI) type toward learning outcomes of main subject of electrolyte and nonelectrolytes solution on of MIA $X$ CLASS SMAN 1 Labuapi West Lombok.
\end{abstract}

Keywords: Problem Based Learning using Group Investigation (GI) type, electrolyte and nonelectrolytes solution main subject 


\section{PENDAHULUAN}

Pendidikan merupakan suatu kebutuhan yang bertujuan meningkatkan kualitas sumber daya manusia serta upaya untuk mewujudkan cita-cita bangsa indonesia dalam mewujudkan kesejahteraan umum serta mencerdaskan kehidupan bangsa. Kegiatan belajar yang efektif merupakan bagian dari proses pendidikan yang bertujuan untuk membawa suatu keadaan kepada keaadaan baru yang lebih baik. Keberhasilan proses pendidikan juga dipengaruhi oleh faktor internal dan eksternal. Faktor internal yaitu kondisi dalam proses belajar yang berasal dari dalam diri sendiri seperti kecerdasan, bakat, keterampilan, minat, motivasi, kondisi fisik dan mental dan faktor eksternal meliputi pemanfaatan prinsip-prinsip pembelajaran seperti pendekatan, model, strategi, dan metode pembelajaran.

Faktor eksternal inilah yang harus dimanfaatkan oleh guru secara maksimal agar faktor internal yang dimiliki peserta didik dapat berkembang secara optimal. Oleh karena itu, untuk melaksanakan tugasnya, tenaga pendidik khususnya guru sangat memerlukan aneka ragam pengetahuan dan keterampilan keguruan yang memadai dalam arti sesuai dengan tuntutan zaman dan kemajuan sains dan teknologi. Salah satu upaya yang dilakukan oleh pendidik adalah mengadakan pembaruan dibidang pendidikan. Pembaruan dibidang pendidikan adalah usaha mengadakan perubahan dengan tujuan untuk memperoleh hal yang lebih baik. Salah satu cara adalah dengan adanya pembaruan kurikulum yaitu dengan menerapkan modelmodel pembelajaran dalam proses belajar mengajar.

Peserta didik pada prinsipnya berhak memperoleh peluang untuk mencapai kinerja akademik dan hasil belajar atau prestasi belajar yang memuaskan agar mampu menjadi generasi penerus yang kompeten dan berdaya saing tinggi. pengamatan dan pemahaman terhadap faktor-faktor yang mempengaruhi prestasi belajar penting sekali artinya dalam rangka membantu murid untuk mencapai prestasi belajar yang sebaik
baiknya(Umatin, 2017). Berdasarkan hasil observasi pada masa Program Pengalaman Lapangan (PPL) di SMAN 1 Labuapi khususnya di kelas X MIA (Matematika dan Ilmu Alam), menunjukkan bahwa guru sudah sering mencoba menerapkan model pembelajaran berbasis masalah, tetapi belum terorganisir dengan baik. Selain itu, salah satu faktor penyebab masih terdapatnya siswa yang kurang aktif adalah adanya rasa tidak percaya diri siswa dengan kemampuan yang dimiliki serta kurangnya interaksi antar siswa selama proses pembelajaran berlangsung. Hal inilah yang menyebabkan hasil belajar siswa belum optimal.

Pada era pembelajaran modern seperti saat ini, dalam interaksi pembelajaran peserta didik tidak hanya berperan sebagai subjek penerima pesan tetapi peserta didik juga bertindak sebagai komunikator atau penyampai pesan. Kondisi tersebut akan menjadikan komunikasi berlangsung secara multi arah, maka proses pembelajaran menjadi berpusat pada peserta didik. Salah satu solusi untuk memperbaiki masalah siswa terhadap pelajaran kimia yaitu penggunaan strategi belajar yang tidak mengharuskan siswa aktif dalam memecahkan permasalahan saja, tetapi strategi yang mendorong siswa untuk mengkonstruksikan pengetahuan di benak mereka sendiri yaitu dengan pendekatan yang mengajak mereka untuk mampu menginvestigasi masalah secara berkelompok yang dapat meningkatkan sifat sosial antar individu, mampu meningkatkan sifat saling menghargai antar individu dalam mengemukakan pendapat, mampu meningkatkan keinginan siswa untuk berbicara dengan orang di sekitarnya. Pendekatan pembelajaran seperti inilah yang disebut model pembelajaran berbasis masalah (Problem Based Learning) dengan tipe Group Investigation (GI). Model pembelajaran berbasis masalah (Problem Based Learning) adalah model pembelajaran yang berdasar pada masalah-masalah yang dihadapi siswa terkait dengan $\mathrm{KD}$ yang sedang dipelajari siswa. Masalah yang dimaksud bersifat nyata atau sesuatu yang menjadi pertanyaanpertanyaan pelik bagi siswa (Kosasih, 2014). Melalui proses pembelajaran berbasis 


\section{Chemistry Education Practice, 1 (1), 2018 - 8}

Pebriana, Sukib, Junaidi

masalah, siswa diharapkan dapat menggali dan menemukan sendiri pemecahan masalah yang diberikan sehingga siswa menjadi pembelajar yang mandiri. Dalam pembelajaran kooperatif, diperlukan pendekatan pengajaran melalui penggunaan kelompok kecil siswa untuk bekerjasama dalam memaksimalkan kondisi belajar dalam mencapai tujuan belajar. Hasil belajar dari pembelajaran berbasis masalah adalah peserta didik memiliki keterampilan penyelidikan, mempunyai keterampilan mengatasi masalah, dan mempunyai kemampuan mempelajari peran orang dewasa, serta dapat menjadi pembelajar yang mandiri dan independen (Suprijono, 2009). Salah satu upaya yang dapat dilakukan oleh pendidik untuk mencapai keberhasilan pembelajaran adalah dengan memperhatikan komponen-komponen pembelajaran yang meliputi: meningkatkan kualitas guru itu sendiri, memperhatikan peserta didik, kurikulum, materi pelajaran, metode pembelajaran dan media pembelajaran yang tepat serta evaluasi (Saputra, 2000). Pemilihan metode pembelajaran yang tepat dapat memotivasi peserta didik untuk semangat belajar, meningkatkan kemampuan berfikir dan mengkonstruksi pengetahuan mereka sendiri tanpa bergantung pada guru. Berdasarkan hal tersebut, maka strategi pembelajaran yang berasosiasi dengan pembelajran kontekstual adalah pembelajaran berbasis masalah (Problem Based Learning) dan pembelajaran kooperatif (Cooperative Learning) dengan tipe Group Investigation (GI) (Umatin, 2017). Dalam pembelajaran cooperative learning tipe Group Investigation (GI) siswa dibentuk dalam suatu kelompok kecil yang saling bekerjasama dalam memecahkan masalah dengan berbagai alternatif jawaban menurut pemikiran mereka sendiri dengan memanfaatkan berbagai sumber informasi yang ada (Suprijono, 2009).

Metode Group Investigatiogghn (GI) ini menuntut para siswa untuk memiliki keterampilan berkomunikasi yang baik dalam kelompok kecil ataupun dengan antar kelompok (Haibah, 2016).

\section{METODELOGI PENELITIAN}

Penelitian ini dimulai dengan tahap persiapan penelitian dari bulan Oktober 2017 dan pelaksanaan penelitian pada bulan April 2018 bertempat di SMAN 1 Labuapi pada siswa kelas $\mathrm{X}$ MIA tahun ajaran. Jenis penelitian yang digunakan dalam penelitian ini adalah eksperimen semu (Quasi Experimental Design). Jenis penelitian ini mempunyai kelompok kontrol, tetapi tidak dapat berfungsi sepenuhnya untuk mengontrol variabel-variabel luar yang mempengaruhi pelaksanaan eksperimen (Sugiyono, 2012). Rancangan penelitian dilakukan pada dua kelas, yaitu satu kelas sebagai kelas kontrol dan satu kelas lainnya sebagai kelas eksperimen. Dalam penelitian ini, perlakuan yang berikan pada kelas eksperimen berupa penggunaan model pembelajaran berbasis masalah (Problem Based Learning) dengan tipe Group Investigation (GI). Sedangkan pada kelas kontrol menggunakan model pembelajaran berbasis masalah. Data akhir diperoleh dengan melakukan post-test di akhir. Variabel yang diamati dalam penelitian ini berupa variabel bebas dan variabel terikat. Variabel bebas merupakan variabel yang mempengaruhi atau menjadi sebab, variabel yang dimaksud adalah model pembelajaran berbasis masalah (Problem Based Learning) dengan tipe Group Investigation (GI). Varibel terikat merupakan variabel yang dipengaruhi atau menjadi akibat, variabel yang dimaksud adalah hasil belajar. pembelajaran materi larutan elektrolit dan non-elektrolit terhadap kedua kelas. Populasi dalam penelitian ini adalah seluruh siswa kelas X MIA SMAN 1 Labuapi yang terdiri dari tiga kelas, yaitu $X$ MIA 1, X MIA 2, X MIA 3, yang seluruhnya berjumlah 71 siswa. Sampel yang digunakan sebanyak 2 kelas yaitu kelas X MIA 1 dan X MIA 2 yang nantinya akan dibagi menjadi kelas eksperimen dan kelas kontrol. Sampel ditentukan setelah uji homogenitas terlebih dahulu, sehingga diperoleh sampel yang homogen. Metode sampling yang digunakan dalam penelitian ini adalah purposive sampling. Penelitian ini menggunakan instrumen berupa tes hasil belajar dalam bentuk tes objektif dengan 5 pilihan jawaban. Instrumen yang telah disusun terlebih dahulu diuji tingkat validitasnya dengan uji validitas isi menggunakan statistik Aiken's V (Azwar, 2012) dan validitas butir soal menggunakan rumus Korelasi Biseral (Arikunto, 2010). Untuk menguji reabilitas instrumen menggunakan rumus K-R 20 (Arikunto, 


\section{Chemistry Education Practice, 1 (1), 2018 - 9}

Pebriana, Sukib, Junaidi

2013). Uji hipotesis dalam penelitian ini menggunakan uji-t (Sugiyono, 2013). Uji-t dilakukan setelah data dianalisis dengan uji normalitas dan homogenitasnya.

\section{HASIL DAN PEMBAHASAN}

Tujuan penelitian ini adalah untuk mengetahui pengaruh model pembelajaran berbasis masalah (Problem Based Learning) dengan tipe Group Investigation (GI) terhadap hasil belajar kimia materi larutan elektrolit dan nonelektrolit siswa kelas $\mathrm{X}$ MIA SMAN 1 Labuapi Lombok Barat. Hasil observasi sebelum penelitian, diperoleh data berupa nilai UTS siswa kelas X MIA. Setelah dilakukan penelitian diberikan post-tes di akhir pertemuan untuk mengetahui hasil belajar siswa yang digunakan dalam uji hipotesis. Hasil belajar siswa yang diperoleh dari penelitian ini adalah hasil belajar pada ranah kognitif yang didapatkan dari nilai post-test. Hasil post-test telah dilakukan pada kedua kelas menunjukkan rata-rata post-test untuk kelas kontrol sebesar 74,28 sedangkan pada kelas eksperimen sebesar 76,08 . Hal ini membuktikan bahwa nilai rata-rata post-test siswa lebih tinggi daripada nilai rata-rata UTS siswa kelas $\mathrm{X}$ MIA SMAN 1 Labuapi semester gasal tahun ajaran 2017/2018. Hal tersebut dapat dilihat dari gambar berikut.

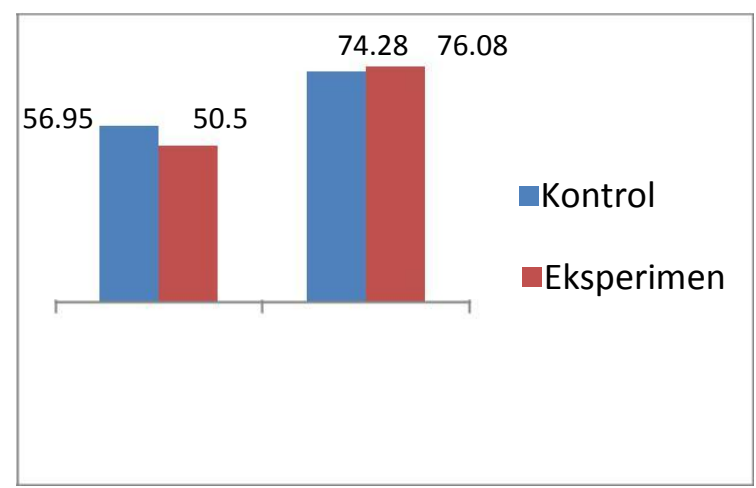

Gambar 5.2 Nilai rata-rata hasil UTS semester gasal kelas $\mathrm{X}$ MIA SMAN 1 Labuapi dan posttest siswa kelas eksperimen dan kelas kontrol

Dari gambar 5.2 dapat dilihat bahwa peningkatan hasil belajar pada siswa kelas kontrol 17,33 yaitu lebih rendah dibandingkan kelas eksperiman yaitu 25,58. Namun, setelah diuji menggunakan uji-t didapatkan bahwa nilai $t_{\text {hitung }}<\mathrm{t}_{\text {tabel }}$ yang artinya Ho diterima. Sehingga dapat disimpulkan bahwa tidak ada pengaruh yang signifikan terhadap penerapan model pembelajaran berbasis masalah (Problem Based Learning) dengan tipe Group Investigation (GI) terhadap hasil belajar materi pokok larutan elektrolit dan nonelektrolit pada siswa kelas X MIA SMAN 1 Labuapi Lombok Barat.

Berdasarkan hasil uji statistik data hasil post-test didapatkan nilai $\chi_{\text {hitung }}^{2}$ untuk kelas X MIA 2 dan X MIA 1 berturut-turut adalah 10,83 dan 10,25 kemudian keduanya dikonsultasikan dengan $\chi_{\text {tabel }}^{2}$ dengan taraf signifikan $5 \%(\mathrm{dk}=5)$ diperoleh $\chi_{\text {tabel }}^{2}$ sebesar 11,07 . Oleh karena kedua kelas memiliki nilai $\chi^{2}$ hitung $<\chi^{2}$ tabel maka data hasil post-test diasumsikan terdistribusi normal.

Berdasarkan perhitungan nilai data post-est kelas $\mathrm{X}$ MIA 2 dan $\mathrm{X}$ MIA 1 didapatkan varians kelas $X$ MIA 2 sebesar 155,06 dan varians kelas X MIA 1 sebesar 121,44 yang merupakan varians terkecil. Dari kedua data tersebut diperoleh nilai $F_{\text {hitung }}$ sebesar 1,27 yang kemudian dikonsultasikan dengan harga $\mathrm{F}_{\text {tabel }}$ dengan dk pembilang $=22$ dan $\mathrm{dk}$ penyebut $=23$ yaitu sebesar 2,03. Oleh karena $F_{\text {hitung }}(1,27)<F_{\text {tabel }}(2,00)$, maka varians kedua kelas tersebut dikatakan homogen.

Pengujian hipotesis dilakukan dengan menggunakan uji-t. Diperoleh nilai $\mathrm{t}_{\mathrm{hitung}}=$ 0,542 . Nilai $t_{\text {hitung }}$ dikonsultasikan dengan harga $t_{\text {tabel }}$ pada taraf signifikan $5 \%$ dan $\mathrm{dk}=$ 45 yaitu sebesar 2,021. Nilai $t_{\text {hitung }}<t_{\text {tabel }}$ hal ini menunjukkan bahwa uji hipotesis menerima Ho yang menyatakan bahwa " Tidak ada pengaruh penerapan model pembelajaran berbasis masalah (Problem Based Learning) dengan tipe Group Investigation (GI) terhadap hasil belajar kimia pokok bahasan larutan elektrolit dan non elektrolit pada siswa kelas X MIA SMAN 1 Labuapi Lombok Barat tahun ajaran 2017/2018.

Sementara, penelitian yang dilakukan oleh Mentari Nur Rizkiyawati (2015) menunjukkan bahwa dengan menerapkan metode Group Investigation (GI) dalam model PBL dapat meningkatkan hasil belajar peserta didik baik itu dalam aspek kognitif, afektif, dan psikomotorik. Hasil belajar dalam 


\section{Chemistry Education Practice, 1 (1), 2018 - 10}

Pebriana, Sukib, Junaidi

aspek kognitif dapat dilihat bahwa peningkatan yang terjadi sebesar 0,53 pada kelas eksperimen, sedangkan pada kelas kontrol peningkatan hanya terjadi sebesar 0,36 . Hal ini disebabkan karena dalam kelas eksperimen peserta didik melakukan diskusi dengan penyelidikan, sehingga peserta didik dapat mengkonstruk pengetahuannya sendiri. Sejalan dengan hasil belajar aspek kognitif, begitu juga dengan aspek afektif dan aspek psikomotorik menunjukkan bahwa dalam kelas eksperimen lebih baik daripada kelas kontrol.

Penelitian selanjutnya yang dilakukan oleh Ando Hutagalung (2015) dengan menggunakan model pembelajaran kooperatif tipe Group Investigation (GI) dapat meningkatkan hasil belajar siswa yaitu nilai rata-rata kelas eksperimen mengalami peningkatan sebesar 43,16 menjadi 75,66. Kecendrungan yang diperoleh dari keberhasilan penelitian ini adalah adanya peningkatan terhadap aktivitas siswa pada setiap pertemuan. Hal yang membedakan keberhasilan dalam penelitian ini adalah penelitian terdahulu memberikan materi investigasi yang berbeda antar kelompok dan guru membagi kelompok secara heterogen dengan mempertimbangkan keakraban persahabatan atau minat yang sama dalam topik tertentu, sedangkan pada penelitian ini memberi suatu materi tugas yang sama antar kelompok dengan harapan bahwa setiap kelompok memiliki pemahaman yang sama terhadap materi yang diberikan oleh guru dalam proses pembelajaran. Perbedaan lainnya, yaitu pada tahap membagi kelompok siswa secara heterogen tanpa mempertimbangkan keakraban persahabatan siswa akan tetapi membagi kelompok dengan mempertimbangkan nilai siswa sebelumnya. Hasil penelitian ini diperoleh bahwa nilai terendah dan tertinggi 50 dan 91,7 dengan ketuntasan klasikal sebesar 58,3\%, sedangkan pada kelas eksperimen adalah 50 dan 95,8 dengan ketuntasan klasikal sebesar 65,2\%.

Meskipun Ho diterima, akan tetapi persentase ketuntasan klasikal siswa kelas kontrol maupun kelas eksperimen mengalami peningkatan dari sebelumnya. Hal ini disebabkan, karena jumlah siswa yang memperoleh nilai tuntas pada saat diberikan post-test setelah diberi perlakuan meningkat dari sebelumnya. Namun, ketuntasan tersebut diperoleh dari data nilai post-test siswa. Meningkatnya hasil belajar siswa dari data nilai post-test tidak dipengaruhi oleh penggunaan model pembelajaran yang diterapkan saja, tetapi keberhasilan meningkatkan hasil belajar siswa dipengaruhi oleh dua faktor yaitu, faktor internal dan eksternal. Faktor internal meliputi: kecerdasan, minat, motivasi, keterampilan, bakat, serta kondisi fisik dan mental siswa, sedangkan salah satu bentuk faktor eksternal yang mempengaruhi peningkatan hasil belajar siswa adalah model pembelajaran yang diterapkan. Tidak adanya pengaruh signifikan yang terjadi di kelas eksperimen pada penelitian ini disebabkan oleh beberapa faktor yaitu pertama, kurang maksimalnya pelaksanaan pembelajaran menggunakan model pembelajaran berbasis masalah (Problem Based Learning) dengan tipe Group Investigation (GI) karena rentang waktu yang pendek. Waktu pelaksanaan penelitian ini selama 2 kali pertemuan dengan satu kali pertemuan untuk pelaksanaan pembelajaran yang menerapkan model pembelajaran berbasis masalah (Problem Based Learning) dengan tipe Group Investigation (GI), satu kali pertemuan untuk memberi penguatan terhadap materi yang sudah disampaikan sebelumnya, serta memberikan post-test pada satu jam terakhir pembelajaran. Hal ini menyebabkan hasil penelitian tidak optimal. Sementara, untuk model pembelajaran PBL jumlah waktu yang dibutuhkan relatif lama (Syaifudin, 2014). Faktor kedua, yang menyebabkan penelitian ini tidak berhasil adalah ketidaksiapan siswa dalam proses pembelajaran. Hal ini sesuai dengan pendapat (Slameto, 2015) bahwa siswa yang telah memiliki kesiapan dalam belajar maka hasil belajarnya akan lebih baik dan begitupula sebaliknya. Pada kelas eksperimen maupun kelas kontrol masih terdapat siswa yang tidak serius dalam mengikuti pelajaran. Banyak siswa yang ijin ketika proses pembelajaran berlangsung di kelas eksperimen dan kelas kontrol. Salah satu yang menyebabkan siswa ijin keluar kelas adalah karena adanya kegiatan ekstrakurikuler, sehingga membuat pembelajaran di dalam kelas terganggu.

Faktor lain yang membuat penelitian ini tidak berhasil adalah sifat siswa yang kurang berpartisipasi untuk mengikuti 


\section{Chemistry Education Practice, 1 (1), 2018 - 11}

Pebriana, Sukib, Junaidi

perintah guru, yaitu ketika menyelesaikan masalah, guru menyarankan siswa untuk mencari solusi tersebut di sumber-sumber belajar yang mereka miliki. Salah satunya adalah buku paket yang diberikan oleh guru. Buku paket tersebut telah diberikan kepada masing- masing siswa sehingga mereka tidak harus meminjam kepada siswa yang lain. Tetapi, hanya siswa tertentu saja yang menggunakan buku tersebut sebagai literatur. Buku yang diberikan hanya bisa digunakan ketika proses pembelajaran berlangsung di dalam kelas dan tidak bisa dibawa pulang sehingga siswa tidak bisa menyelesaikan tugasnya dengan tepat waktu, sehingga siswa hanya memanfaatkan rangkuman yang telah peneliti berikan untuk melengkapi penunjang belajar siswa dan dirasakan tidak terlalu efektif.

Faktor ketiga, yang menyebabkan penelitian ini tidak berhasil adalah kurangnya kekompakan yang dimiliki oleh masingmasing kelompok dengan anggota kelompoknya masing-masing. Hal ini karena, banyak diantara kelompok siswa yang lebih memilih untuk bertanya akan solusi dari masalah yang telah diberikan kepada kelompok yang lain daripada bertanya kepada anggota kelompoknya sendiri bahkan tidak bertanya sama sekali. Peristiwa ini terjadi baik dikelas eksperimen maupun kelas kontrol. Hal itulah yang menyebabkan proses pemecahan masalah baik di kelas eksperimen maupun kelas kontrol tidak efektif.

Faktor keempat, yang menyebabkan penelitian ini tidak berhasil adalah adanya beberapa kendala yang terjadi pada kegiatan inti. Kendala pertama, yaitu ketika melaksanakan persentasi. Waktu yang diberikan untuk melakukan persentasi dikatakan cukup, namun banyak siswa yang tidak memperhatikan perwakilan dari masingmasing kelompok untuk menyampaikan hasil diskusinya. Sehingga situasi kelas tidak bagus karena tidak terjadi diskusi antar kelompok tetapi yang terjadi adalah keributan dan kesibukan sendiri yang dilakukan oleh siswa. Sehingga, dirasakan diskusi tidak berjalan efektif. Kendala kedua, yaitu siswa dikelas eksperimen masih belum terbiasa dengan model pembelajaran yang diterapkan sehingga siswa masih kaku dan bingung untuk mengerjakan sesuatu meskipun guru sudah menjelaskan beberapa kali. Sedangkan dikelas kontrol, siswa sudah mengerti dengan model pembelajaran yang diterapkan, karena model pembelajaran ini merupakan model yang sudah pernah diterapkan oleh gurunya yaitu, model pembelajaran berbasis masalah (Problem Based Learning). Faktor terakhir yang menyebabkan penelitian ini tidak berhasil adalah kurangnya kesiapan siswa ketika menghadapi post-test yang dilaksanakan pada pertemuan terakhir meskipun telah diinformasikan pada pertemuan sebelumnya. Post-test dilakukan pada waktu 1 jam terakhir pembelajaran. Pada kelas eksperimen post-test dilakukan pada 1 jam terakhir setelah keluar bermain. Sedangkan pada kelas kontrol post-test dilakukan 1 jam terakhir setelah melaksanakan solat dzuhur berjamaah. Karena untuk 2 jam pertama baik di kelas eksperimen maupun kelas kontrol telah dilakukan penguatan terhadap materi yang telah dipelajari sebelumnya. Meskipun demikian, sebagian siswa masih saja mengatakan bahwa mereka belum siap untuk melaksanakan tes. Akan tetapi, tes tetap dilakukan karena sesuai dengan jadwal dan perjanjian yang telah ditentukan oleh siswa dan guru.

\section{KESIMPULAN}

Berdasarkan data hasil penelitian dan pembahasan, dapat disimpulkan bahwa penerapan model pembelajaran berbasis masalah (Problem Based Learning) dengan tipe Group Investigation (GI) tidak dapat memberikan pengaruh yang signifikan terhadap hasil belajar materi pokok larutan elektrolit dan nonelektrolit pada siswa kelas X MIA SMAN 1 Labuapi Lombok Barat.

\section{SARAN}

Berdasarkan penelitian yang telah dilakukan, peneliti mengajukansaran untuk keberlanjutan penelitian ini yaitu: 1). Diharapkan untuk peneliti berikutnya agar memperhatikan faktor-faktor lain yang berpengaruh terhadap hasil belajar siswa agar penelitian dapat berjalan sesuai dengan yang diharapkan; 2). Diharapkan untuk peneliti selanjutnya dapat memperhatikan kembali langkah-langkah dari model pembelajaran yang diterapkan pada penelitian ini; 3). Dapat melakukan penelitian ini pada sampel yang 
lebih besar dan luas sehingga diharapkan dapat melihat efektivitas pendekatan model pembelajaran yang diteliti dalam aspek yang lebih luas; 4). Diharapkan untuk peneliti selanjutnya agar lebih memahami model pembelajaran yang diterapkan dalam proses penelitian; 5). Diharapkan untuk peneliti selanjutnya dapat meminimalisir kelemahankelemahan dari model yang diterapkan pada penelitian ini.

\section{DAFTAR PUSTAKA}

Arikunto, S. (2010). Prosedur Penelitian Suatu Pendekatan Praktik. Jakarta: Rineka Cipta.

Arikunto, S. (2013). Dasar-Dasar Evaluasi Pendidikan. Jakarta: Bumi Aksara.

Azwar, S. (2012). Reliabiltas Dan Validitas. Yogyakarta : Pustaka Pelajar.

Haibah, M. (2016). Implementasi Model Pembelajaran Group Investigation Dengan Permainan Bendera Pintar Untuk Meningkatkan Minat Belajar Dan Pemahaman Konsep Ekonomi Siswa Kelas X Ipa 3 Sman 1 Jetis Bantul Tahun Ajaran 2015/2016. Skripsi. Universitas Negri Yogyakarta.

Hutagalung, A. (2015). Pengaruh Model Pembelajaran Kooperatif Tipe Group Investigation Terhadap Hasil Belajar Siswa. Jurnal Infapi, 3(1).

Kosasih, E. (2014). Strategi Belajar Dan Pembelajaran. Bandung : Yrama Widya.

Nur, R. M. (2015). Implementasi Group Investigation (GI) Dalam Model
PBL Materi Redoks Untuk Meningkatkan Kemampuan Pemecahan Masalah Siswa SMAN 2 Batang. Skripsi. FMIPA Universitas Negri Semarang. Pada Pembelajaran Ipa (Fisika) Di Smp. Skripsi Pada Fpmipa Universitas.

Purwanto. (2009). Evaluasi Hasil Belajar. Yogyakarta : Pustaka Pelajar.

Saputra, Dkk. (2000). Strategi Pembelajaran. Malang : Fip Um.

Slameto. (2015). Belajar Dan Faktor-Faktor Yang Mempengaruhi. Jakarta: Rineka Cipta.

Sugiyono. (2012). Metode Penelitian Pendidikan: Pendekatan Kuantitatif, Kualitatif, Dan R\&D. Bandung: Alfabeta.

Sugiyono. (2013). Metode Penelitian Pendidikan Pendekatan Kuantitatif, Kualitatif, Dan R\&D. Bandung: Alfabeta.

Suprijono, A. (2009_. Cooperative Learning. Yogyakarta : Pustaka Pelajar.

Syaifudin, M. (2014). Model Problem Based Learning Disertai Media Audiovisua. Pada Pembelajaran Ipa (Fisika) Di Smp. Skripsi Pada Fpmipa Universitas Jember.

Umatin, C. (2017). Aplikasi Problem Based Learning Dan Group Investigation Dalam Pembelajaran Ekonomi Di Man Malang I. Konstruktivisme, 9(1). 